\title{
Projeto A.M.I.G.A. - Pecuária leiteira e sustentabilidade
}

Augusto José Savioli de Almeida Sampaio, Wilmar Sachetin Marçal, João Pedro Marmol de Oliveira*

Universidade Estadual de Londrina (UEL), Londrina, PR, Brasil

*Autor correspondente

e-mail: joao.marmol@gmail.com

\section{Resumo}

A cidade de Londrina é rodeada por inúmeras pequenas propriedades rurais, geridas por famílias que têm como principal fonte de renda, em sua maioria, a agropecuária, encontrando na pecuária leiteira uma alternativa de renda mensal regular. Tais atividades permitem o crescimento e consolidação das ações extensionistas na região. Criando predominantemente bovinos mestiços, a maioria sobrevive da comercialização de leite e derivados de maneira informal, sem a devida assessoria do médico veterinário. Com esse cenário, desenvolveu-se na Universidade Estadual de Londrina um projeto de extensão rural com o objetivo de mudar a realidade desses produtores. As propriedades atendidas pelo projeto encontram-se na região de Londrina, em um raio de até 50 quilômetros, cuja característica principal é a dificuldade em custear assistência profissional veterinária. As mesmas são cadastradas e, com agendamento prévio, são visitadas de acordo com a necessidade ou consulta da disponibilidade da equipe, formada por discentes, docentes e residentes. Cria-se, assim, um campo de atuação e aplicação dos conhecimentos adquiridos pelos graduandos do curso através da grade curricular ofertada, nas diversas áreas de atuação do profissional de medicina veterinária, sempre com a supervisão direta de docentes, vivenciando a apresentação de enfermidades, medicando animais, orientando os produtores sobre manejo, prevenção de enfermidades e, principalmente, de zoonoses. 0 atendimento clínico veterinário e a assistência técnica, na orientação da produção, constituem-se num apoio logístico essencial aos pequenos produtores rurais, permitindo a diminuição das perdas na produção, gerando aumento na renda familiar, de modo a incentivar princípio da sustentabilidade, promovendo diretamente o fomento à pecuária leiteira do pequeno produtor carente através de assistência e orientação veterinária, e colaborando para a diminuição do êxodo rural. Esta ação itinerante é totalmente gratuita, e os medicamentos utilizados são obtidos através de laboratórios colaboradores, minimizando ainda mais os custos dos pequenos produtores e perdas na produção. No 
período entre janeiro de 2014 e março de 2017, foram realizados 651 procedimentos na área de medicina veterinária preventiva, 474 na área de clínica cirúrgica, 227 na clínica médica e 137 na área de reprodução animal. Através dessas ações, é possível agregar valor aos produtos ofertados pela propriedade, aumentando a captação de renda e permitindo a estimulação e fixação das famílias ao campo. Para o grupo de alunos participantes, além do convívio com a prática veterinária, também é agregada uma vivência acadêmica enriquecedora. 0 envolvimento social entre os integrantes da equipe assistente e de seus assistidos contribui para a formação de profissionais mais conscientes do meio em que vivem, a partir da observação in loco das atuações profissionais. Os resultados parciais permitem as primeiras conclusões de que a melhoria nas técnicas de produção e sanidade animal, com assistência veterinária constante, têm agregado valor aos produtos oriundos dessas propriedades rurais, obtendo maior aceitação no mercado. 